\title{
Comparison of Different Internal Implants for Repair of Hind Limb Fracture
}

\author{
Farah Ijaz ${ }^{1}$, Shehla Gull Bukhari², Muhammad Faiz Qamar², Iahtasham Khan ${ }^{2}$, M. Bilal Haider², \\ Muhammad Asif ${ }^{2}$, Ghulam Abbas ${ }^{3, ",}$ Muhammad Arshad Javed ${ }^{2}$, Hira Anjum², Hafiz Kashif Shezad ${ }^{2}$, \\ Aun Muhammad ${ }^{2}$
}

\author{
${ }^{1}$ Department of Clinical science, College of Veterinary and Animal Sciences, Jhang, Pakistan \\ ${ }^{2}$ University of Veterinary and Animal Sciences, Lahore, Pakistan \\ ${ }^{3}$ Department of Animal Production, Riphah College of Veterinary Sciences, Lahore, Pakistan
}

Copyright $\subseteq 2018$ by authors, all rights reserved. Authors agree that this article remains permanently open access under the terms of the Creative Commons Attribution License 4.0 International License

\begin{abstract}
Bone fracture is termed as any discontinuity in the integrity of bone structure. Basic principal of treatment of fracture include reduction and retention. Modern age has developed number of methods to treat fracture; one of them is usage of Compression plate that are held in place with the help of screws. Limited Contact Dynamic Compression Plate (LC-DCP) is the new version of Dynamic Compression Plate (DCP) and is better than DCP in terms of providing aid in early healing, playing its role as providing low degree of plate-bone contact and decreased incidence of porosity and better vascularization, which reduces healing time and optimizes callus formation, leading to early healing and return of limb function.
\end{abstract}

Keywords Bone Fracture, LC-DCP, DCP

\section{Introduction}

Musculoskeletal system holds its importance in the maintenance of body function, biggest of them being support of viscera. Musculoskeletal system includes multiple organs like skin, bones, tendon, ligaments and cartilages. Bones are the main holding framework of body accompanied with ligament and tendon to act as supportive structures. Femur is the largest and longest bone of all and is responsible to bear most of the weight of hind quarter. Any force applied to the bone surpassed the bone strength causes bone fracture. These forces may be physiological forces and non-physiological forces. Non-physiological forces are trauma from an auto mobile, gunshot wound and falls. While physiological forces are weight bearing, muscle contraction and associate functions (Hulse 2003). Overall chances of fracture in dogs are $29.94 \%$ (Tercavlioglu 2009). Treatment of fracture has two basic principles; 1-reduction of the fracture fragments, and 2-retention of fractured fragments. Bone plates and screws are one of the many choices to treat fracture. Primary bone plate system is Dynamic Compression Plate (DCP) in which holes are designed in such a way that they cause compression of fracture fragments (Roe 2003). Bone plates and screws are indicated when it is desired to restore the functional ability of affected limb early (Fossum 2003). A modification of DCP is Limited Contact-Dynamic Compression Plate (LC-DCP) and Point-Contact Fixation. LC-DCP has its advantage over DCP as stress is not concentrated at the screw holes with lesser infection rate and early callus formation.

The purpose of this study is to evaluate the latest two plate fixation system; i.e DCP and LC-DCP, in terms of appropriate fracture reduction, implant position, early fracture healing, lesser infection rate, early callus formation and better vascularization of the bone. The results were evaluated on the basis of Radiographic findings and B-Mode Sonography, where by early callus formation evidence and fewer infection rates were admitted in group subjected to LC-DCP. Early callus formation showed better implant and early healing time.

\section{Materials and Methods}

The experimental trial was performed on 8 mongrel dogs of either sex. Dogs were divided into two groups, A and B comprising four dogs each. The dogs were assigned names and groups as follow:

Group 1: A1, A2, A3, A4

Group 2: B1, B2, B3, B4

In group 1, DCP was applied on long oblique femoral fracture while in group 2, LC-DCP was applied on long oblique femoral fractures. 


\section{Pre-operative Examination of Dogs and Medication:}

A complete visual and thorough physical examination. Bathing of animals with Luke warm water and antibacterial soaps. Prophylactic measures against rabies in the form of Rabicin vaccine. Fenbendazole at the rate of $6 \mathrm{mg} / \mathrm{kg}$ body weight for controlling of internal worms and Trichlorphan powder for bathing to control external parasites, examination of femur prior to surgery by $5.0 \& 7.5 \mathrm{MHz}$ transducer ultrasonography to eliminate any sort of confusion regarding bone health and condition prior to surgery.

\section{Instrument and Their Preparation}

Periosteal elevator, lowman's bone clamp, Bone Plates of 2 sizes (DCP $3.5 \mathrm{~mm}$ broad \& LC-DCP $3.5 \mathrm{~mm}$ broad), bone drill machine of $2.7 \& 3.5 \mathrm{~mm}$ size, bone saw, $3.5 \mathrm{~mm}$ screws, bone hammer, depth gauge, bone chisel, 20 gauge orthopedic wire, lag screws $3.5 \mathrm{~mm}$ fully threaded varying in length between $30 \mathrm{~mm} 32 \mathrm{~mm}$ and $34 \mathrm{~mm}$ as per needed, screw driver hexagonal type for $3.5 \mathrm{~mm}$ screws, bone tape $3.5 \mathrm{~mm}$, wire cutter, wire twister along with common surgical pack used for soft tissue surgery including scissors, forceps, needle holders, scalpel handles, artery clamp, muscle retractor, trays, towel and needle plus disposable sterilized surgical blades, gauzes, gloves, caps and masks.

All orthopedic and general surgical instruments were autoclaved prior to use.

\section{Pre-anesthetic Medication}

Atropine sulphate and Xylaine I/M as pre-anesthetic \& sedative, respectively at the dose rate of $0.02 \mathrm{mg} / \mathrm{kg}$ and 0.4 $\mathrm{mg} / \mathrm{kg}$ body weight before induction of general anesthesia.

\section{Anesthetic Medication}

Animals were anesthetized by using ketamine at the dose rate $\mathrm{f} 5 \mathrm{mg} / \mathrm{kg}$ in combination with Xylaine in 2:1 with ketamine. Half dose was given as a bolus while remaining half was given as maintenance anesthesia, with regular checking of vitals. After the surgical stage of anesthesia was achieved operation was begum. Prior to surgery Ringer's Lactate was given at the dose rate of $10 \mathrm{ml} / \mathrm{kg}$ body weight.

\section{Preparation of the Patient}

Surgical site was clipped and shaved off from lateral and median sides from point of hip to toe. Area was cleaned by using antiseptic scrubbing solution. Sterile surgical drapes were places around the surgical site leaving a rectangular window opened at proposed surgical site. The first layer of drape was placed in four drapes fashion and was secured to the patient skin by towel clamp. The first drape was placed in such fashion that the central opening area covered the limb and whole body of animal. Then four drapes fashion was secured to patient by towel clamp as the patient hind quarter was covered. Entire lower portion of limb was also covered in drapes to ascertain asepsis.

\section{Surgical Technique}

For the surgical procedure animal was placed in lateral recumbency with limbs to be operated on top. Femur was exposed through a cranio-lateral approach. Then afterwards, a long oblique fracture was induced; after adequate reduction, the respective bone plate was applied in each group.

Femur was exposed by standard surgical protocol and was subjected to a long oblique fracture approximately twice the width of the bone was induced in the femoral mid shaft using bone saw. Induced fracture was stabilized with the help of bone plates. Firstly, it was reduced by using bone clamps with the goals of ideal reduction and preventing bone from rotation. A fully threaded $3.5 \mathrm{~mm}$ cortical screw was applied in lad fashion, perpendicular to the fractured site for additional stability. Then plates were approximated over bone. Holes were drilled with the help of drill machine and grooves were cut with the help of bone tap. Plates were fixed with the help of cortical screws occupying both cortices of the bone (Roe 2003).

Plated system used in both groups was

DCP was applied to Group A

LC-DCP was applied to Group B

\section{Insertion of Fully-threaded Cortical Screws in Lag Fashion}

A $3.5 \mathrm{~mm}$ fully-threaded cortical screw was used in dog A4 with $24 \mathrm{~mm}$ length in lag fashion. Keeping at least $1 \mathrm{~cm}$ distance from the fractured ends, a gliding hole equal to diameter of screw thread was drilled in near cortex. Threaded hole, equal to diameter of screw core was drilled in far cortex and tapped with $2.7 \mathrm{~mm}$ bone tap. As screw engages far cortex compression along fracture line was occurred. Hole was drilled so that inserted screw bisected an angle between perpendicular to the axis of bone and perpendicular to fracture line, size of screws was different according to bone diameter.

\section{Post-operative Management}

Operated animals were kept in germ-free, ventilated, compatible and bio-secured cages. An average of $500 \mathrm{ml}$ Ringer's Lactate solution was infused intravenously BD to combat dehydration and acidosis in first week. From day 2 post operatively, milk and chicken were given as diet to compensate the losses during surgery and to combat the stress during healing procedure. Antibiotic therapy was launched using Ceftriaxone sodium as $500 \mathrm{mg} / \mathrm{kg}$ body weight, injected intravenously for 7 days after surgery. For 
first five days injection Dicloran sodium was given to relieve from the pain along with injection Pherasym was given as antihistaminic to prevent self-mutilation of the suture line by the patients due to itching. Wound was daily dressed using antiseptic solution (10\% pyodine) and mycitracin cream up till complete healing of the suture.

The femur with internal fixation implants (i.e DCP \& LC_DCP) were examined by B-mode ultrasonography using $7.5 \mathrm{MHz}$ transducer, on day 1 post-operatively and then after every week, respectively for any complication. During this whole procedure behavior, TPR, feeding, defecation and urination were monitored regularly.

\section{Experimental Parameters}

Operated animals were kept for the experimental period of three months and the efficacy of the internal implants were evaluated on the basis of the following parameters.

\section{Physical Evaluation}

Gait and lameness analysis, Presence of pain, Vital signs (temperature, pulse, respiration), Signs of osteomyelitis.

\section{Radiographic Findings}

The animals were restrained in the lateral recumbency and the radiographs of femurs were obtained through a medial-lateral projection (ACOMA, JAPAN). The radiographs were obtained at an interval of 15-days to examine the progress of callus formation with respect to each plate fixation system. The radiographs also made it convenient to visualize the implant position and ascertain proper reduction of the fracture.

\section{Ultrasonographic Findings}

Sonograms were obtained in the lateral recumbency with the help of $7.5 \mathrm{MHz}$ curvilinear transducer through B-mode Ultrasonography (Aloka, JAPAN). Sonograms were recorded at an interval of seven days. For sonographical examination femur was approached from medial side of the thigh, as it is better technique to explore the fracture line (Van Bree, 2005).

\section{Histopathology}

A histopathological study was also conducted. At the end of 12 week of surgery the site was opened surgically, plates were removed, and evidence of neo-vascularization was assessed in Group A (DCP) the bone showed lesser vascularization in areas of plate bone contact and plate screw insertion. Comparably in group B (LC-DCP) implants showed evidence of decreased cortical porosity and decreased denuded areas at plate-bone interface and at site of screw insertion.

\section{Results}

\section{Physical Findings}

Gait and lameness analysis, presence of pain, vital signs (temperature, pulse, respiration)

\section{1-Gait and Lameness Analysis}

Table 1. Grading of both groups at walking

\begin{tabular}{|c|c|}
\hline Degree & Lameness \\
\hline- & No lameness \\
\hline+ & Mild lameness \\
\hline++ & Obvious lameness \\
\hline+++ & Marked lameness \\
\hline++++ & Three-legged lameness \\
\hline
\end{tabular}

Table 2. Lameness grading in Group A(DCP) at walk

\begin{tabular}{|c|c|c|c|c|c|c|}
\hline $\begin{array}{c}\text { Dog } \\
\text { no }\end{array}$ & $\begin{array}{c}\mathbf{2}^{\text {nd }} \\
\text { week }\end{array}$ & $\mathbf{4}^{\text {th }}$ week & $\mathbf{6}^{\text {th }}$ week & $\mathbf{8}^{\text {th }}$ week & $\begin{array}{c}\mathbf{1 0}^{\text {th }} \\
\text { week }\end{array}$ & $\begin{array}{c}\mathbf{1 2}^{\text {th }} \\
\text { week }\end{array}$ \\
\hline A1 & $\begin{array}{c}+++ \\
+\end{array}$ & +++ & ++ & ++ & + & + \\
\hline A2 & +++ & +++ & ++ & + & + & - \\
\hline A3 & $\begin{array}{c}+++ \\
+\end{array}$ & Expired & Expired & Expired & Expired & Expired \\
\hline A4 & +++ & ++ & ++ & + & + & - \\
\hline
\end{tabular}

\section{Assumption}

From above table it is assumed that in $50 \%$ animals three-legged lameness was shown, while in other $50 \%$ marked lameness was shown. Lameness is recovered in research trial in $\operatorname{dogs} \mathrm{A} 2$ and $\mathrm{A} 4$. While $\operatorname{dog} \mathrm{A} 1$ showed mall-union and $\operatorname{dog} \mathrm{A} 3$ expired in $3^{\text {rd }}$ week.

Table 3. Lameness grading in Group B (LC-DCP) at walk

\begin{tabular}{|c|c|c|c|c|c|c|}
\hline $\begin{array}{c}\text { Dog } \\
\text { no }\end{array}$ & $\begin{array}{c}\mathbf{2}^{\text {nd }} \\
\text { week }\end{array}$ & $\mathbf{4}^{\text {th }}$ week & $\mathbf{6}^{\text {th }}$ week & $\mathbf{8}^{\text {th }}$ week & $\begin{array}{c}\mathbf{1 0}^{\text {th }} \\
\text { week }\end{array}$ & $\begin{array}{c}\mathbf{1 2}^{\text {th }} \\
\text { week }\end{array}$ \\
\hline B1 & - & - & - & - & - & - \\
\hline B2 & - & - & - & - & - & - \\
\hline B3 & $\begin{array}{c}+++ \\
+\end{array}$ & Expired & Expired & Expired & Expired & Expired \\
\hline B4 & - & - & - & - & - & - \\
\hline
\end{tabular}

\section{Assumption}

From above table it is assumed that lameness is absent in $75 \%$ of animals. While in $25 \%$ it is severe. B3 was expired later due to osteomyelitis. 
Table 4. Changes in temperatures, pulse and respiration of dogs in both groups 1-2 week post-operatively

\begin{tabular}{|c|c|c|c|c|c|c|}
\hline Parameters & \multicolumn{2}{|c|}{ Temperature(faranhite) } & \multicolumn{2}{|c|}{$\begin{array}{c}\text { Respiration } \\
\text { breaths/minute }\end{array}$} & \multicolumn{2}{c|}{$\begin{array}{c}\text { Pulse } \\
\text { beats/minute }\end{array}$} \\
\hline Day & Group A & Group B & $\begin{array}{c}\text { Group } \\
\text { A }\end{array}$ & $\begin{array}{c}\text { Group } \\
\text { B }\end{array}$ & $\begin{array}{c}\text { Group } \\
\text { A }\end{array}$ & $\begin{array}{c}\text { Group } \\
\text { B }\end{array}$ \\
\hline 1 & 101 & 102.3 & 25 & 26 & 115 & 112 \\
\hline 2 & 105 & 103 & 23 & 26 & 109 & 114 \\
\hline 3 & 104 & 101 & 22 & 24 & 110 & 108 \\
\hline 4 & 105 & 103 & 20 & 23 & 105 & 106 \\
\hline 5 & 105 & 102 & 20 & 22 & 104 & 105 \\
\hline 6 & 103 & 105 & 19 & 21 & 101 & 103 \\
\hline 7 & 103 & 102 & 20 & 21 & 105 & 101 \\
\hline 8 & 105 & 103 & 18 & 20 & 100 & 101 \\
\hline 9 & 101 & 102 & 18 & 20 & 98 & 99 \\
\hline 10 & 103 & 104 & 15 & 19 & 95 & 97 \\
\hline 11 & 104 & 102 & 17 & 20 & 96 & 96 \\
\hline 12 & 105 & 103 & 16 & 19 & 96 & 95 \\
\hline 13 & 105 & 105 & 15 & 17 & 88 & 85 \\
\hline 14 & 104 & 101 & 16 & 16 & 89 & 88 \\
\hline
\end{tabular}

\section{Pain Grading}

All dogs showed normal routine without exhibit of severe pain except for $\operatorname{dog}$ A1 and A3 in Group A (DCP) and $\mathrm{B} 3$ in group $\mathrm{B}$ (LC-DCP). But these dogs responded well to Diclofenac sodium injection very next day. Response to pain was recorded in according to following scale.

Table 5. Pain Grading Scale

\begin{tabular}{|c|c|}
\hline Pain type & Grade \\
\hline None & 1 \\
\hline Mild & 2 \\
\hline Moderate & 3 \\
\hline Severe & 4 \\
\hline Unbearable & 5 \\
\hline
\end{tabular}

Table 6. Average Value of Pain Grading in Group A

\begin{tabular}{|c|c|c|c|c|c|c|c|}
\hline Dogs & $\begin{array}{c}\mathbf{1}^{\text {st }} \\
\text { day }\end{array}$ & $\begin{array}{c}\mathbf{2}^{\text {nd }} \\
\text { week }\end{array}$ & $\begin{array}{c}4^{\text {rd }} \\
\text { week }\end{array}$ & $\begin{array}{c}\mathbf{6}^{\text {th }} \\
\text { week }\end{array}$ & $\begin{array}{c}\mathbf{8}^{\text {th }} \\
\text { week }\end{array}$ & $\begin{array}{c}\mathbf{1 0}^{\text {th }} \\
\text { week }\end{array}$ & $\begin{array}{c}\mathbf{1 2}^{\text {th }} \\
\text { week }\end{array}$ \\
\hline A1 & 4 & 4 & 3 & 3 & 2 & 2 & 2 \\
\hline A2 & 3 & 3 & 3 & 2 & 2 & 2 & 1 \\
\hline A3 & 4 & 4 & Expired & & & & \\
\hline A4 & 3 & 3 & 3 & 3 & 3 & 2 & 1 \\
\hline
\end{tabular}

\section{Assumption}

From above table it is assumed that there was severe pain in 50\% animals and moderate pain in other 50\% animals at start. Later on, controlled but A1 had pain throughout the trial.
Table 7. Average value of pain grading in group B

\begin{tabular}{|c|c|c|c|c|c|c|c|}
\hline Dogs & $\begin{array}{c}\mathbf{1}^{\text {st }} \\
\text { day }\end{array}$ & $\begin{array}{c}\mathbf{2}^{\text {nd }} \\
\text { week }\end{array}$ & $\begin{array}{c}\mathbf{4}^{\text {rd }} \\
\text { week }\end{array}$ & $\begin{array}{c}\mathbf{6}^{\text {th }} \\
\text { week }\end{array}$ & $\begin{array}{c}\mathbf{8}^{\text {th }} \\
\text { week }\end{array}$ & $\begin{array}{c}\mathbf{1 0}^{\text {th }} \\
\text { week }\end{array}$ & $\begin{array}{c}\mathbf{1 2}^{\text {th }} \\
\text { week }\end{array}$ \\
\hline B1 & 3 & 3 & 3 & 2 & 2 & 1 & 1 \\
\hline B2 & 3 & 3 & 2 & 2 & 1 & 1 & 1 \\
\hline B3 & 4 & 4 & Expired & & & & \\
\hline B4 & 3 & 3 & 2 & 2 & 2 & 1 & 1 \\
\hline
\end{tabular}

\section{Assumption}

From above table it is assume that $75 \%$ experimental animals had moderate pain and just $25 \%$ had severe pain which was controlled later in research trial.

\section{Statistics}

Table 8. Results of Lameness grading in both group B Dogs (LC-DCP) and Group A (DCP) at walk

\begin{tabular}{|c|c|c|}
\hline & Group A & Group B \\
\hline Mean & 44.44444444 & 4.166666667 \\
\hline Variance & 776.1437908 & 91.91176471 \\
\hline Pooled Variance & 434.0277778 & \\
\hline Hypothesized Mean Difference & 0 & \\
\hline Df & 34 & \\
\hline $\mathrm{t}$ Stat & 5.8 & \\
\hline $\mathrm{P}(\mathrm{T}<=\mathrm{t})$ one-tail & $7.8317 \mathrm{E}-07$ & \\
\hline $\mathrm{t}$ Critical one-tail & 1.690924198 & \\
\hline $\mathrm{P}(\mathrm{T}<=\mathrm{t})$ two-tail & $1.56634 \mathrm{E}-06$ & \\
\hline $\mathrm{t}$ Critical two-tail & 2.032244498 & \\
\hline
\end{tabular}

Key: Mean of DCP is 44.444 which are more than 4.166 of LC-DCP and $\mathrm{P}<1.566 \mathrm{E}-07(00000001.566)$ which shows $\mathrm{P}$ value is less than 0.05 the value of $\tilde{\alpha}$ so it shows that the both groups had not equal lameness score and group $\mathrm{B}(\mathrm{LC}-\mathrm{DCP})$ have less lameness as compared to Group A(DCP)

Table 9. Result of value for pain grading in Group B (LC-DCP) and Group A(DCP)

\begin{tabular}{|c|c|c|}
\hline & Group A & Group B \\
\hline Mean & 2.571428571 & 2 \\
\hline Variance & 0.657142857 & 0.7 \\
\hline Pooled Variance & 0.678571429 & \\
\hline Hypothesized Mean Difference & 0 & \\
\hline Df & 40 & \\
\hline $\mathrm{t}$ Stat & 2.247805948 & \\
\hline $\mathrm{P}(\mathrm{T}<=\mathrm{t})$ one-tail & 0.015085106 & \\
\hline $\mathrm{t}$ Critical one-tail & 1.683851014 & \\
\hline $\mathrm{P}(\mathrm{T}<=\mathrm{t})$ two-tail & 0.030170212 & \\
\hline $\mathrm{t}$ Critical two-tail & 2.02107537 & \\
\hline
\end{tabular}

Key: Mean of DCP is 2.571 which are more than 2 of LC-DCP and $\mathrm{P} \leq$ 0.03017 which shows $P$ value is less than 0.05 the value of $\alpha$ so it shows that the both groups had not equal pain score and group B(LC-DCP) have less pain as compared to Group A(DCP) 


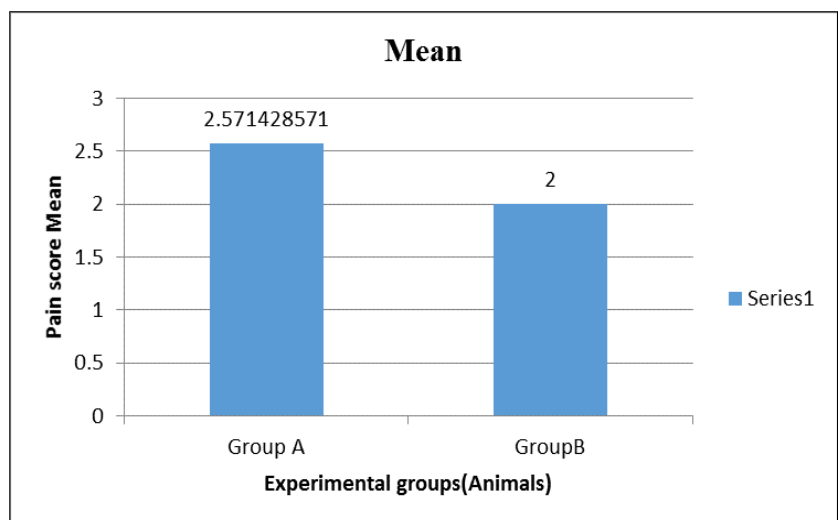

Figure 1. Pain Scores (Mean) in Group A (DCP) and Group B (LC-DCP) Dogs. DCP: Mean=2.571; LC-DCP: Mean=2, P $\leq 0.03017 *$ (significant); Pain scoring was done based on the following chart: $-5(100 \%), 4$ (75\%), 3 (50\%), 2 (25\%), 1(0\%)

From table it is concluded that signs of pain were severe in Group A (DCP) and in group B (LC-DCP) pain signs were less comparably.

\section{Radiographic Findings}

Radiographs were obtained for each dog by positioning each dog in lateral recumbancy with medio-lateral projection (ACOMA JAPAN DF-50) at an interval of two weeks of examine the callus formation subjected to each fixation plate system.

Table 10. Post-surgical Radiographic Evaluation in Group A (DCP)

\begin{tabular}{|c|c|c|c|c|c|c|}
\hline $\begin{array}{l}\mathrm{Sr} \\
\text { no }\end{array}$ & $\begin{array}{c}1^{\text {st }} \text { day after } \\
\text { surgery }\end{array}$ & $2^{\text {nd }}$ week & $4^{\text {th }}$ week & $8^{\text {th }}$ week & $12^{\text {th }}$ week & $16^{\text {th }}$ week \\
\hline A1 & $\begin{array}{c}\text { Plate } \\
\text { perfectly } \\
\text { placed with } \\
\text { orthopedic } \\
\text { wire as } \\
\text { auxiliary } \\
\text { implant }\end{array}$ & $\begin{array}{l}\text { Cerclage } \\
\text { wire } \\
\text { slightly } \\
\text { deviated }\end{array}$ & $\begin{array}{c}\text { No good } \\
\text { apposition } \\
\text { due to } \\
\text { slight } \\
\text { deviation } \\
\text { but callus } \\
\text { formation } \\
\text { began }\end{array}$ & $\begin{array}{l}\text { Quite big } \\
\text { callus } \\
\text { formation }\end{array}$ & $\begin{array}{c}\text { Enlarge } \\
\text { callus seen }\end{array}$ & Mal-union \\
\hline A2 & \begin{tabular}{|c|} 
Principle \\
rightly \\
applied with \\
lag screw \\
fixation
\end{tabular} & $\begin{array}{c}\text { Reduction } \\
\text { was } \\
\text { perfect }\end{array}$ & $\begin{array}{c}\text { Ideal } \\
\text { apposition }\end{array}$ & $\begin{array}{c}\text { Ideal } \\
\text { callus } \\
\text { formation }\end{array}$ & $\begin{array}{l}\text { Visible } \\
\text { callus }\end{array}$ & $\begin{array}{l}\text { Re-union } \\
\text { of bone } \\
\text { fragments }\end{array}$ \\
\hline A3 & $\begin{array}{c}\text { Plate is exact } \\
\text { on } \\
\text { cranio-lateral } \\
\text { aspect of } \\
\text { fracture }\end{array}$ & $\begin{array}{c}\text { Plate was } \\
\text { displaced } \\
\text { and lag } \\
\text { screws } \\
\text { freely } \\
\text { movable } \\
\text { in the } \\
\text { bone }\end{array}$ & $\begin{array}{l}\text { Dog } \\
\text { expired }\end{array}$ & & ----" & ---- \\
\hline A4 & $\begin{array}{c}\text { Good } \\
\text { reduction } \\
\text { achieved }\end{array}$ & \begin{tabular}{|c|} 
Fixation \\
device \\
perfectly \\
applied \\
\end{tabular} & $\begin{array}{c}\text { Reduction } \\
\text { was ideal }\end{array}$ & $\begin{array}{c}\text { Medium } \\
\text { sized } \\
\text { callus } \\
\text { seen }\end{array}$ & $\begin{array}{c}\text { Mineralized } \\
\text { callus } \\
\text { formation }\end{array}$ & $\begin{array}{c}\text { Complete } \\
\text { union } \\
\text { resulted }\end{array}$ \\
\hline
\end{tabular}

\section{Discussion}

The present experiment was conducted to compare two implants and internal fixation of femoral fractures. Their efficacy (DCP \& LC-DCP) was evaluated based on lameness at walk and trot, pain scoring, ultrasonography, radiography and histopathological basis. Both groups were evaluated and group B ( $2^{\text {nd }}$ gave clear indications that LC-DCP resulted in quicker recovery as compared to
Table 11. Post-surgical Radiographic Evaluation in Group B (LC-DCP)

\begin{tabular}{|c|c|c|c|c|c|c|}
\hline $\begin{array}{l}\mathrm{Sr} \\
\text { no }\end{array}$ & $\begin{array}{l}1^{\text {st }} \text { day } \\
\text { after } \\
\text { surgery }\end{array}$ & $2^{\text {nd }}$ week & $4^{\text {th }}$ week & $8^{\text {th }}$ week & $12^{\text {th }}$ week & $\begin{array}{c}16^{\text {th }} \\
\text { week }\end{array}$ \\
\hline B1 & $\begin{array}{c}\text { Plate } \\
\text { perfectly } \\
\text { placed } \\
\text { with lag } \\
\text { screw } \\
\text { fixation }\end{array}$ & $\begin{array}{c}\text { Fixation } \\
\text { is good }\end{array}$ & $\begin{array}{c}\text { Good } \\
\text { opposition } \\
\text { of bone } \\
\text { fragments }\end{array}$ & $\begin{array}{c}\text { Good } \\
\text { mineralized } \\
\text { callus } \\
\text { formation }\end{array}$ & $\begin{array}{c}\text { Medium } \\
\text { sized callus } \\
\text { formation }\end{array}$ & $\begin{array}{c}\text { complete } \\
\text { union }\end{array}$ \\
\hline B2 & $\begin{array}{c}\text { Good } \\
\text { reduction } \\
\text { achieved } \\
\text { with lag } \\
\text { screw } \\
\end{array}$ & $\begin{array}{c}\text { Fixation } \\
\text { devices } \\
\text { not } \\
\text { perfectly } \\
\text { applied }\end{array}$ & $\begin{array}{c}\text { Reduction } \\
\text { is not } \\
\text { ideal }\end{array}$ & $\begin{array}{c}\text { Large sized } \\
\text { callus } \\
\text { formation }\end{array}$ & $\begin{array}{c}\text { Visible } \\
\text { callus seen }\end{array}$ & $\begin{array}{c}\text { no good } \\
\text { union } \\
\text { resulted }\end{array}$ \\
\hline B3 & $\begin{array}{c}\text { Reduction } \\
\text { and } \\
\text { fixation } \\
\text { with bine } \\
\text { screws and } \\
\text { plate is up } \\
\text { to the mark }\end{array}$ & $\begin{array}{c}\text { Fixation } \\
\text { device } \\
\text { slightly } \\
\text { displace }\end{array}$ & $\begin{array}{c}\text { Dog } \\
\text { expired }\end{array}$ & & & \\
\hline B4 & $\begin{array}{c}\text { Principle } \\
\text { rightly } \\
\text { applied } \\
\text { with lag } \\
\text { screws }\end{array}$ & $\begin{array}{c}\text { Reduction } \\
\text { was } \\
\text { perfect }\end{array}$ & $\begin{array}{c}\text { Rate of } \\
\text { callus } \\
\text { formation } \\
\text { was good } \\
\text { due to } \\
\text { ideal } \\
\text { fixation }\end{array}$ & $\begin{array}{c}\text { Medium } \\
\text { sized callus } \\
\text { seen }\end{array}$ & $\begin{array}{c}\text { Mineralized } \\
\text { callus } \\
\text { formation }\end{array}$ & $\begin{array}{l}\text { Ideal } \\
\text { bone } \\
\text { union }\end{array}$ \\
\hline
\end{tabular}

\section{Ultrasonographic Findings}

Sonograms were also obtained in the lateral recumbancy with the help of $7.5 \mathrm{MHz}$ curvilinear transducer through B-mode ultrasonography (Aloka JAPAN S900) to access signs of early healing. Sonograms were recorded at an interval of one week.

\section{Histopathology}

Present project was also evaluated by histopathological studies. At the end of 12 week the site was opened surgically, the plates were removed, and evidence of neo-vascularization was assessed in Group A (DCP), the bone showed lesser vascularization in areas of plate bone contact and plate screw insertion. Comparably in group B (LC-DCP) implants showed evidence of decreased cortical porosity and decreased denuded areas at plate bone interface and at the site of screw insertion. 
Group A (DCP). All dogs of Group B (LC-DP) showed modern pain signs and recovered well with time span as compared to Group A (DCP). Radiographic and ultrasonographic evaluation of dogs A2 and A4 in Group A showed good callus formation, while dog A1 suffered osteomyelitis in $3^{\text {rd }}$ week. Dog A3 expired in third week post operatively. Contrastingly, in group B, reduction and fixation of fractured fragments was ideal and dogs regained $100 \%$ limb function early in the healing phase, as evidenced by callus formation and complete bone union. Besides this histopathological examination at the end of $12^{\text {th }}$ week showed evidence of superiority of LC-DCP over DCP. In Group A bone showed lesser vascularization and in the areas of plate bone contact and plate screw insertion. Comparably in Group B implants showed evidence of decreased cortical porosity and decreased denuded areas at the plate-bone interface and at site of screw insertion.

\section{Conclusions}

Based on present experimental trail on dogs, it was concluded that the use of Limited Contact Dynamic Compression Plate (LC-DCP) holds an edge over the conventional Dynamic Compression Plate. LC-DCP promises low degree of plate-bone contact and decreased incidence of osteo-porosity and better vascularization, which reduces healing time and optimizes callus formation, leading to early return of limb function as evidenced through all the parameters specially ultrasonography, radiography and histopathology.

\section{REFERENCES}

[1] S.T Arens, M. Hansis U. Schlegal, H. Eijer G. Printzen, W.J Ziegler and S.M Perren (2000). Infection after open reduction and internal fixation with dynamic compression plates-Clinical and experiment data Anaylsis. Vol. 27, suppl. 3, S-C27-S-C33.

[2] K. Bosscha, and J.P. Snellen (1993). Internal fixation of metacarpal and Phalangeal fracture with AO minifragment screws and plates: a prospective study. Injury 24(3):166-168.

[3] Z. Feng, L.Li, D. He, C.Yang and Y. Qiuk (2011). Role of retention of condylar cartilage in open treatment intracapsular condylar fractures in growing goats: three dimentional computed tomographic analysis. $\mathrm{Br} \mathrm{J}$ Oral Maxillofac Surg. 50: 523-527.

[4] D Filipowicz,O. Lanz,,S. Elder and S.Werre (2009). A biomechanical comparison of 3.5 locking compression plate fixation to 3.5 limited contact dynamic compression plate fixation in a canine cadaveric distal humeral metaphyseal gap model. Vet Comp Orthop Traumatol. 22(4): 270-7.

[5] K.K. Firoozbaksh, M.S, E.Moneim, and M.A. Pirela-Cruz (1993).Comparative fatigue strengths and stabilities of metacarpal internal fixation technique. J Hand Surg[Am]. 18(6):1059-68.

[6] Fischer, K.J, J.A, D.A. Provenzano and M.M. Tomaino (1999). Low-profile versus conventional metacarpal plating system: a comparison of construct stiffness and strength. J Hand Surg[AM]. 24(5)928-34.

[7] C.M. Gauthier, B.P. Conrad, D.D. Lewis and A. Pozzi(2011). In vitro comparison of stiffness of plate fixation of radii from large- and small-breed dogs. Am J Vet Res. 72(8): 1112-7.

[8] E. Gautier and S.M. Perren (1992). Limited Contact Dynamic Compression Plate (LC-DCP) biomechanical research as basis to new plate design. Orthopade. 21(1): $11-23$.

[9] G.R. Grant and R.B. Olds (2003). Treatment of open fractures. Eds, Slatter. Text book of Small Animal Surgery. Philadelphia USA, Pp 1793-1797.

[10] D. Hulse and B. Hyman (2003). Fracture biology and biomechanics. Eds, Slatter. Text Book of Small Animal Surgery, Philadelphia USA, Pp 1785-1792.

[11] K. Jermyn and S.C. Roe (2011). Influence of screw insertion order on compression generated by bone plates in a fracture model. Vet Comp OrthopTraumatol. 24(6): 403-7.

[12] K. Klauce, and S.M. Perren (1988). Internal fixation with a self-compressing plate and lag screw: Improvement of plate hole and screw design. I. Mechanical investigation. Journal of Orthopedic Trauma. 5(3):280-288.

[13] G. Lazar and F.P. Schulter-Ellis (1980). Intramedullary structure of humen metacarpals. J Hand Surg[Am]. 5(5); $477-81$.

[14] T. Lögters, J. Windolf and P. Flohé (2009). Femoral shaft fractures. The trauma surgeon journal of the German Society of Trauma Surgery $\mathbb{C}$ Springer-Verlag 200910.1007/s00113-009-1669-

[15] Lucas, G.L. and C.M. Pfeiffer (1989). Osteotomy of the metcarpal and phalanges stabilized by AO plates and screws. Ann Chir Main. 8(1):30-8.

[16] S.M. Perren, K. Klaue, O. Pohler, M.Predieri, S.Steinemann and E. Gautier (1990). The limited-contact dynamic compression plate (LC-DCP). Arch Orthop Trauma. 9(6): 304-10.

[17] Rand, J.A, K.N. An, E.Y. Chao and P.J. Kelly (1981). A comparison of the effect of intramedullary nailing and compression plate fixation on fracture site blood flow and fracture union. J Bone Joint Surg Am. 63(3):427-42.

[18] M. Risselada M, H.V. Bree, M. Kramer, H.DRooster, O.Taeymans and Verleyene (2005). Ultrasonographic and radiographic assessment of uncomplicated secondary fracture healing of long bones in dogs and cats. Vet. Surg 34(2); 99-107.

[19] M. Risselada, H.B. Bree, M. Kramer, L. Duchateau, P. Verleyen and J.H. Saunders (2007). Ultrasonographic assessment of fracture healing after plate osteosynthesis. .Vet Radiol Ultrasound. 48(4): 368-72.

[20] S. Roe (2003). Internal fracture fixation. Eds, Slatter. Text book of Small Animal Surgery. Philadelphia USA. Pp 1798-1802. 
[21] M. Stephan and Perren. (2002). Evolution of the internal fixation of long bone fractures. J Bone surg. 84-B: 1093-1110.

[22] K.S. Stiffler (2004). Internal fracture fixation. Clinical Tech Small Animal Practice. 19 (3): 105-13.
[23] H. Tercanlioglu and M. Sarieler (2009). LucrariStiintifice Medicina Veterinar. Vol XLII. 2. Pp 98-101. 